\title{
THE IMPACT OF THE OVERTIME PREMIUM ON EMPLOYMENT AND HOURS IN U.S. INDUSTRY
}

\author{
RONALD G. EHRENBERG * \\ University of Massachusetts
}

A rational manpower policy must seek to create new jobs as well as to provide training for the unemployed. The creation of new jobs has been hindered by the tendency of employers to utilize overtime hours rather than increase employment levels, even while significant numbers of workers were unemployed. Undoubtedly, a large proportion of the overtime hours was due to transitory phenomena such as rusl orders, seasonal demand, absenteeism, and mechanical failure. Nevertheless, it is our contention that large amounts of overtime are regularly sclieduled by employers for rational economic reasons. In addition to the specific investment costs of labor discussed by S. Rosen [6] [7] and M. Nadiri and S. Rosen [5], there exist substantial supplementary compensation costs per man which are quasi-fixed in the sense of being independent of the exact number of hours per week that each employee works. These inciude employers' costs for items such as paid vacations and holidays, private welfare and insurance plans, and many legally-required insurance payments. ${ }^{\prime}$ The higher these costs relative to the overtime wage rate, the more likely that employers will substitute overtime for additional employment.

This paper presents empirical estimates of the intraindustry cross-section relationship between annual overtime hours per man and the ratio of these quasi-fixed costs to the overtime wage rate. Estimates are also made of the impact of a change in the overtime premium on employment and hours; these estimates have implications for policymakers concerned with the wisdom of increasing the overtime premium as a method of job creation.

The data for the computations were derived from unpublished individual establishment reports released to us from the Bureau of Labor Statistics' survey of "Employer Expenditures for Selected Compensation Practices, 1966." This survey provided the best available source of information on overtime hours, employment, and employer expenditures for

\footnotetext{
*This paper summarizes the policy implications of my doctoral dissertation [3]. Without implicating them for what remains, I am grateful to Professors F. Brechling, G. Delehanty, and D. Mortensen for constructive comments during my dissertation research and to the Editor of this Journal for comments on an earlier verston of the paper. The research was supported by a grant from the Manpower Administration of the U.S. Department of Labor under the Manpower Development and Training Act of 1962, as amended.

1. Garbarino [4] was one of the first to consider the economic impact of these costs. That they have been steadily increasing as a percentage of total labor costs over the post-war period, is indicated in [13], $[14]$, and $\{15\}$.
} 
various compensation categories, at the individual establishment level. ${ }^{2}$ The sample included 4,009 establishments drawn from the U.S. private nonagricultural sector. ${ }^{3}$

Tables 1 and 2 present, for each two-digit manufacturing industry and for major nonmanufacturing industry groups, the mean and intraindustry standard deviation of observed annual overtime per man in 1966, calculated for the establishments in the sample. ${ }^{4}$ In most cases the intraindustry variation is substantial, and the coefficient of variation varies across industries. This implies that cross-section regressions that use industry mean values as the units of observation, such as those found in Rosen [7] and Van Atta [8], may obscure the underlying relationships. Consequently, we concentrate on explaining the causes of intraindustry variations in overtime hours per man.

Theory suggests that annual overtime hours per man would be influenced by the relationship between quasi-fixed labor costs and the overtime wage rate, as well as by other characteristics of the firm. For each of the two-digit manufacturing industries and each of the nonmanufacturing industry groups with a sufficient number of establishments to conduct a meaningful analysis, a linear overtime equation incorporating these characteristics was estimated: 5

2. The U.S. Chamber of Commerce [9] has been collecting similar data biennially. Their samples are significantly smaller, and coverage is blased more towards larger establishments than the B.L.S. survey.

3. Nonproduction workers are excluded from the analysis since they are exempt from the overtime provisions of the Fair Labor Standards Act and are not usually paid on an hourly basis.

4. The calculated means need not conform to those published for the manufacturing industries in [12] since the latter are weighted averages based on a much larger sample of establisluments. The large proportion of nonmanufacturing establishments reporting zero overtime is due to the survey definition of overtime as hours of work for which premium pay was received. Since the nonmanufacturing industries were not uniformly covered by the overtime provisions of [16] in 1966, many of these establishments may have actually worked their employees overtime but falled to pay them an overtime premium. For technical reasons, it was therefore necessary to exclude these zero overtime establishments from the analysis $[3$, p. 145.50]. As a result, the Communications industry (S.I.C. 48) was not represented in the final sample.

5. The theoretical framework on which the estimation is based is discussed in [1] and [2]. A logelinear form of the overtine equation was estimated, but the linear specification appeared to be marginally better. Proxy variables had to be constructed for $H, Q, S$, and $A$. The explicit methods of calculating all variables and the complete regression results are given in an appendjx available from the author. The coefficients for the proxy variables were often statistically insignificant.

The five industries for which the sample sizes were too small were Ordinance and Accessories (S.I.C. 19), Tobacco (S.I.C. 21), Petroleum (S.I.C. 29), Leather (S.I.C. 31) and Instruments (S.I.C. 38). From a policy point of view, these industries were fortunately habitually among the seven manufacturing industries with the least overtime over the 1956.60 period. In 1966 they accounted for less than five percent of the aggregate weekly overtime hours worked in manufacturing [11, p. A17].

Transitory variables such as recent rates of increase in demand in relation to capacity undoubtedly also affect the level of overtime. Data for such variables are unavailable at the individual establisliment level, and from a statistical point of view there is no reason to assume that such varjables would be correlated with any of the observed explanatory variables. The omission of these variables should therefore not bias the estimates. 
Table 1. Annual Overtime Hours Per Man, Manufacturing Establishments, 1966

$\begin{array}{lrrrr}\text { Industry } & \begin{array}{c}\text { S.I.C. } \\ \text { Code }\end{array} & \begin{array}{c}\text { Number of } \\ \text { Establishments }\end{array} & \begin{array}{c}\text { Mean } \\ \text { (Hours) }\end{array} & \begin{array}{r}\text { Standard } \\ \text { Deviation } \\ \text { (Hours) }\end{array} \\ \text { Ordinance } & 19 & 5 & 338.244 & 108.009 \\ \text { Food } & 20 & 86 & 164.511 & 165.090 \\ \text { Tobacco } & 21 & 5 & 94.293 & 111.812 \\ \text { Textile } & 22 & 143 & 187.598 & 127.401 \\ \text { Apparel } & 23 & 150 & 58.702 & 63.835 \\ \text { Lumber } & 24 & 31 & 169.596 & 156.258 \\ \text { Furniture } & 25 & 22 & 149.523 & 128.553 \\ \text { Paper } & 26 & 33 & 309.199 & 199.622 \\ \text { Printing } & 27 & 37 & 145.411 & 129.210 \\ \text { Chemicals } & 28 & 40 & 189.189 & 146.718 \\ \text { Petroleum } & 29 & 13 & 78.276 & 62.343 \\ \text { Rubber } & 30 & 24 & 221.510 & 142.938 \\ \text { Leather. } & 31 & 19 & 74.258 & 56.390 \\ \text { Stone-Clay.Glass } & 32 & 110 & 214.014 & 141.541 \\ \text { Primary Metals } & 33 & 77 & 220.541 & 122.468 \\ \text { Fabricated Metals } & 34 & 92 & 206.807 & 151.789 \\ \text { Machinery } & 35 & 82 & 261.412 & 174.796 \\ \text { Electric Equipment } & 36 & 63 & 146.228 & 102.644 \\ \text { Transportation Equipment } & 37 & 47 & 227.383 & 153.210 \\ \text { Instruments } & 38 & 16 & 215.169 & 131.441 \\ \text { Miscellaneous Manufacturing } & 39 & 24 & 139.768 & 140.552 \\ & & & & \end{array}$

Table 2. Annual Overtime Hours Per Man, Nonmanufacturing Establishments, 1966

\begin{tabular}{|c|c|c|c|c|c|}
\hline & \multicolumn{3}{|c|}{ Number of Establislıments } & \multicolumn{2}{|c|}{ Positive Overtime Establishments } \\
\hline & $\begin{array}{l}\text { S.I.C. } \\
\text { Code }\end{array}$ & Total & $\begin{array}{l}\text { Positive } \\
\text { Overtime }\end{array}$ & $\begin{array}{c}\text { Mean } \\
\text { (Hours) }\end{array}$ & $\begin{array}{c}\text { Standard } \\
\text { Deviation } \\
\text { (Hours) }\end{array}$ \\
\hline Mining & $10-14$ & 38 & 37 & 152.287 & 132.765 \\
\hline Construction & $15-17$ & 508 & 285 & 125.217 & 171.272 \\
\hline Transportation & 40,42 & 314 & 239 & 186.645 & 171.272 \\
\hline Utilities & 48,49 & 188 & 184 & 121.731 & 73.306 \\
\hline Wholesale Trade & 50 & 340 & 244 & 188.992 & 211.959 \\
\hline Retail Trade & $52-59$ & 330 & 172 & 110.051 & 146.416 \\
\hline Finance, Insurance & 60.66 & 49 & 25 & 122.222 & 108.292 \\
\hline Services & $70-89$ & 246 & 89 & 89.819 & 115.160 \\
\hline Total & & 2013 & 1275 & & \\
\hline
\end{tabular}




$$
T=a_{0}+a_{1}(C / W)+a_{2} H+a_{3} Q+a_{4} S+a_{5} A+a_{6} U
$$

where

$T=$ observed annual overtime hours per man

$C=$ nonwage labor costs per manweek (legally required insurance payments such as unemployment compensation and social security; payroll costs such as vacation, holiday, leave and bonus payments; employers' contributions to life and health insurance plans and to union welfare funds, including severance and S.U.B. funds)

$W=$ the overtime premium wage calculated from the data

$H=$ the number of hours per week after which an overtime premium must be paid

$Q=$ the establishment quit rate

$S=$ the ratio of new to senior workers

$A=$ the establishment absentee rate

$U=$ a dummy variable representing the presence of collective bargaining

The regression coefficients for the $(C / W)$ variable are presented in column 1 of Table 3. The most striking conclusion from this column is that the coefficient is positive, as expected, in all 24 industry groups: an increase in the ratio of the quasi-fixed costs relative to the overtime wage rate causes a substitution of overtime hours for employment. Moreover the coefficient is statistically significant at the 95 percent level for 12 of the 16 manufacturing and 6 of the 8 nonmanufacturing industries. ${ }^{6}$ of the four manufacturing industries in which the coefficient is not significant, two (Lumber-S.I.C. 24 and Furniture-S.I.C. 25) are represented by relatively small sample sizes. The Transportation Industry (S.I.C. 37) is dominated by automobile manufacturing which is well known for its seasonal pattern of overtime among heterogeneous groups (production workers during peak production periods, retooling workers during model changes). Finally, the Stone, Clay and Glass Industry (S.I.C. 32) is a diverse conglomeration of both continuous process and seasonal industries. We should expect that it is erroneous to lump all the diverse component three-digit industries together when studying overtime behavior.

Similarly, the two nonmanufacturing industries with nonsignificant coefficients are again the industries with the smallest number of observations in the nonmanufacturing sample. Payments into union welfare funds in a

6. A more theoretically appropriate measure for $(C / W)$ that included in the denominator those fringe costs that vary directly with hours of work was also calculated. The correlation between the two measures was exceedingly ligh in all industries (at least ,97) and regression results using the alternative varjables differed only marginally. 
Table 3. Overtime and Employment Changes Resulting From a

Change in the Overtime Premium

\begin{tabular}{|c|c|c|c|c|c|c|c|}
\hline & $\begin{array}{c}(C / W) \\
\text { Coefficient } \\
\text { (1) }\end{array}$ & $\begin{array}{c}\text { Mean } \\
\text { Value } \\
(C / W \mid \\
(2)\end{array}$ & $\begin{array}{c}\text { Mean } \\
\text { Value } \\
\text { Overtime } \\
\text { (3) }\end{array}$ & $\begin{array}{c}\text { Elasticity of } \\
\text { Overtime } \\
\text { w.r.t. } \\
(C / W) \\
\text { (4) }\end{array}$ & $\begin{array}{c}\text { Average } \\
\text { Decrease } \\
\text { Overtime } \\
\text { Per Man } \\
\text { (5) }\end{array}$ & $\begin{array}{c}\text { Percent } \\
\text { Decrease } \\
\text { Overtime } \\
\text { Per Man } \\
\text { (6) }\end{array}$ & $\begin{array}{c}\text { Percent } \\
\text { Increase } \\
\text { Employment } \\
(7)\end{array}$ \\
\hline Food & 26.398 & 5.215 & 183.740 & .749 & 34.416 & 18.7 & 1.7 \\
\hline Textile & 29.898 & 3.918 & 194.395 & .602 & 29.285 & 15.1 & 1.5 \\
\hline Apparel & 5.137 & 4.843 & 69.883 & .356 & 6.220 & 8.9 & .3 \\
\hline Lumber & * 9.876 & 4.351 & 210.300 & .204 & 10.743 & 5.1 & .5 \\
\hline Furniture & $* 21.930$ & 4.056 & 149.523 & .637 & 22.237 & 14.9 & 1.1 \\
\hline Paper & 85.758 & 5.737 & 309.199 & 1.591 & 122.998 & 39.8 & 6.2 \\
\hline Printing & 25.793 & 4.592 & 153.720 & .796 & 29.610 & 19.3 & 1.5 \\
\hline Chemicals & 25.805 & 6.190 & 194.040 & .823 & 39.993 & 20.6 & 2.0 \\
\hline Rubber & 40.429 & 5.446 & 221.510 & .993 & 55.044 & 24.8 & 2.8 \\
\hline Stone-Clay-Glass & $* 11.029$ & 6.099 & 215.977 & .247 & 16.816 & 7.8 & .8 \\
\hline Primary Metals & 19.727 & 5.564 & 221.287 & .496 & 27.440 & 12.4 & 1.4 \\
\hline Fabricated Metals & s 26.392 & 5.626 & 209.055 & .710 & 37.120 & 17.8 & 1.9 \\
\hline Machinery & 33.695 & 5.764 & 271.339 & .715 & 48.554 & 17.9 & 2.4 \\
\hline $\begin{array}{l}\text { Electric } \\
\text { Equipment }\end{array}$ & 32.481 & 5.443 & 151.023 & 1.170 & 44.199 & 29.3 & 2.2 \\
\hline $\begin{array}{c}\text { Transportation } \\
\text { Equipment }\end{array}$ & * 4.121 & 4.495 & 214.195 & .086 & 4.631 & 2.2 & .2 \\
\hline Miscellaneous & & & & & & & \\
\hline Manufacturing & 53.146 & 5.245 & 159.735 & 1.745 & 69.688 & 43.6 & 3.5 \\
\hline Mining & * .343 & 6.644 & 152.287 & .014 & .570 & .4 & 0.0 \\
\hline Construction & 30.959 & 3.331 & 125.217 & .822 & 25.756 & 20.6 & 1.3 \\
\hline Transportation & 42.888 & 5.734 & 186.645 & 1.317 & 60.058 & 32.2 & 3.0 \\
\hline Utilities & 7.899 & 6.988 & 121.731 & .454 & 13.782 & 11.3 & .7 \\
\hline Wholesale Trade & 39.093 & 5.110 & 188.992 & 1.057 & 49.941 & 26.4 & 2.5 \\
\hline Retail Trade & 35.101 & 3.911 & 110.051 & 1.247 & 35.022 & 31.8 & 1.8 \\
\hline $\begin{array}{l}\text { Finance, } \\
\text { Insurance and } \\
\text { Real Estate }\end{array}$ & & & & & & & \\
\hline $\begin{array}{l}\text { Real Estate } \\
\text { Services }\end{array}$ & $\begin{array}{r}* 14.673 \\
40.370\end{array}$ & $\begin{array}{l}5.997 \\
3.958\end{array}$ & $\begin{array}{r}122.222 \\
89.819\end{array}$ & $\begin{array}{r}.719 \\
1.779\end{array}$ & $\begin{array}{l}21.998 \\
39.946\end{array}$ & $\begin{array}{l}18.0 \\
44.5\end{array}$ & $\begin{array}{l}1.1 \\
2.0\end{array}$ \\
\hline
\end{tabular}

*Regression coefficient not statistically significantly different from zero at .95 level of significance.

segment of the Mining industry are also a function of the number of tons of coal produced rather than the number of men employed. Given this method of financing fringe benefits, we should not expect the $(C / W)$ variable to have a significant impact on overtime in this industry. Thus, in spite of the six statistically nonsignificant coefficients, the general conclusion affirms the role of the quasi-fixed supplementary compensation costs in influencing the overtime-employment trade-off.

This conclusion must be qualified, however, by noting that within each 
two-digit manufacturing industry, both the size and significance of the regression coefficient vary across different component three-digit industries and different size classes of establishments. Similar results concerning the component industries hold for the nonmanufacturing coefficients. Within each nonmanufacturing industry, however, the coefficients appear to be statistically significant for almost all classes of establishments, with the size of the coefficients being fairly uniform. ${ }^{7}$ Thus the responses to a change in the overtime premium estimated below must be considered only as average responses within an industry. It appears that the impact of an overtime premium is not uniform across all establishments in an industry.

Given these qualifications, we can attempt to answer the question "What would the effect of an increase in the overtime premium be, ceteris paribus, on the number of overtime hours worked per man and the level of employment?" Columns 2 and 3 list the mean values of $(C / W)$ and annual overtime per man within an industry, as calculated for the establishments in our sample. ${ }^{8}$ The estimated elasticity of annual overtime per man with respect to $(C / W)$ evaluated at the means of both variables is shown in column 4 . Since the denominator of $(C / W)$ is equal to the overtime wage rate, the elasticity of overtime per man with respect to the overtime premium can then be directly calculated.

More interesting than the elasticity estimates, is the effect of a given discrete change in the overtime premium on overtime and employment. Since the proposed Congressional Overtime Pay Penalty Act of 1964 [10] considered increasing the overtime premium from one and a half to twice the straight time hourly wage, the effects of such a change are evaluated here. An increase in the overtime premium of that magnitude would decrease $(C / W)$ by twenty-five percent. Multiplying the coefficient of $(C / W)$ (column 1) by one-quarter the mean value of $(C / W)$ (column 2 ) yields the average decrease in annual overtime per man for each industry (column 5 ). The average decrease would vary between an insignificant five hours and a substantial one hundred and twenty-three hours per year. In percentage terms (column 6) the decrease would be between two and forty-three percent. For twelve of the manufacturing industries, the percentage reduc-

7. The rationale for allowing the $(C / W)$ coefficient to vary with establishment size within an industry and across component industries within a major industry group is discussed, along with the results, in [3, Ch. 4-5].

8. The sample data permitted calculation of the average overtime premium paid for each establishment that had positive overtime [3, p. 198]. The premium was almost uniformly time-and-a-half and this figure is used in the analysis that follows. The restriction to positive overtime establishments eliminated less than four percent of the manufacturing sample from the analysis. This elimination explains why the mean values of overtime in Table 1 are often slightly less than the comparable mean values in column 3 of Table 3. 
tion would be greater than ten percent. Apparently a significant portion of overtime hours worked in manufacturing industries in 1966 could have been eliminated by this increase in the overtime premium.

Estimates of the increase in employment that would result can be obtained, if we postulate that total man-hours demanded by each establishment would not be altered by the change in the overtime premium. If the decreases in overtime could all be translated into new full-time employment opportunities, each new employee working two thousand hours per year, the resulting percentage increase in employment would be given by [(column 5)/2000] (100). These estimates are presented in column 7 and are remarkably stable; for the majority of the industries the increase is one to three percent. If these estimates are applied to actual 1966 manufacturing industry production worker employment levels, the overall percentage increase in employment in the sixteen industries would have been about 1.6 percent, corresponding to an increase in employment of approximately 218,500 full-time employees. ${ }^{9}$ Naturally, if part of the decreases in overtime were translated into part-time employment opportunities, the benefits would be spread over a larger number of the unemployed.

Similar results for the nonmanufacturing industries are also presented in Table 3. For those firms that initially worked positive overtime, the estimated hours and employment changes are comparable to the manufacturing results. Again for the majority of the industries, the estimated percentage increases in employment range from one to three percent. Since a large number of the nonmanufacturing establishments in the sample initially reported zero overtime and were excluded from the analysis, the actual percentage increases in employment would be substantially smaller.

It should be recognized that these estimates at best provide upper bounds to the true employment gains. We have neglected supply side responses of currently employed workers faced simultaneously with an increase in the overtime premium and a reduction in hours of work. One plausible response is increased moonlighting at part-time jobs, thereby reducing the creation of new jobs for the unemployed. More crucially, the

9. These calculations are based on industry employment figures given in $[12]$. In 1966, production worker employment in these industries was approximately $13,616,000$. Our estimated percentage increase in employment of $1.6 \%$ for 1966 is remarkably similar to Van Atta's [8] estimate of $1.5 \%$ for 1965 . Van Atta utilized aggregate annual time-serles data for manufacturing production workers during the 1947.65 period to estimate the impact of $(C / W)$ on overtime hours. The ratio of fringe benefits to the overtime wage rate moved in an almost stendy upward trend during this period. Consequently, in addition to problems of aggregation, Van Atta's estimated regression coefficient may have captured the impact of any other variables with trends that may have been omitted from her analysis. In spite of thase difficulties, the conformity of our result with hers is worth noting. 
assumption that an increase in the overtime premium will not change firms' total man-hours demanded is obviously erroneous. An increase in the overtime premium raises the cost of labor services relative to capital services and should cause a shift towards more capital-intensive methods of production. Moreover, if product prices subsequently also increase, decreasing the quantities demanded of final products, then total manhours demanded will decrease even further. ${ }^{10}$

Data limitations prevent us from estimating the small scale econometric model that would be required to obtain quantitative information as to the magnitude of each of these effects. Consequently, the actual impact of an increase in the overtime premium on employment cannot be ascertained. Nevertheless, the estimated "upper-bounds" should be of interest to policymakers. Our own personal view is that given the potential inflationary impact of such a policy and the apparent variation of the $(C / W)$ coefficient among and within industries, increasing the overtime premium does not appear to be an effective method of decreasing unemployment.

10. In [1] and [2] it was shown that equilibrium hours per man will be invariant to scale, given certain plausible assumptions. Consequently our estimated decreases in overtime hours per man are not biased upward, as the employment increases are.

\section{REFERENCES}

1. R. Ehrenberg, "Absenteeism and the Overtime Decision," Amer. Econ. Rey., June 1970, 60, 352-57.

2. cision," Jour. Econ. Theory, March 1971, 3, 85-103.

3. $\longrightarrow$ The Short-Run Employment Decision and Overtime Behavior in U.S. Industry, 1966, Unpublished doctoral dissertation, Northwestern Univ., 1970.

4. J. Garbarino, "Fringe Benefits and Overtime as Barriers to Expanding Employment," Ind. and Labor Rel. Rev., Apr, 1964, 17, 426-42.

5. M. Nadiri and S. Rosen, "Interrelated Factor Demand," Am. Econ. Rev., Sept. 1969, 59, 457-71.

6. S. Rosen, "Short-Run Employment Variation on Class-I Railroads in the U.S.," Economerrica, July/Oct. 1968, 36, 511-29.

7.

8. S. Van Atta, An Analysis of Overtime Hours for Production Workers in Manufacturing Indus. tries, 195 7.65, Unpublished doctoral dissertation, Univ. of California, Berkeley, 1967.

9. Clamber of Commerce of the United States, Fringe Benefits, various issues 1947-67.

10. U.S. Congress, House, Subcommittee on Labor, Overtime Pay Penalty Act of 1964: Hearing on H.R. 1680 and 9802,88 th Cong., 2d sess., 1964.

11. U.S. Department of Labor, Premium Pay for Overtime Under the Fair Labor Standards Act November 1967 (submitted to Congress, 1968).

12. Bureau of Labor Statistics, Employment and Earnings Statistics for the United States, 1909.67, Bulletin 1312-5, 1967. 
13. - Employer Expenditures for Selected Remuneration Practices for Production Workers in Mamufacturing Industries, 1959, Bulletin 1308, Jan. 1962.

14. ___ Employer Expenditures for Selected Supplementary Compensation Practices for Pro. duction and Related Workers, Manufacturing Industries, 1962, Bulletin 1428, Apr. 1965.

15. Employee Compensation in the Private Nonfarm Economy, 1966, Bulletin 1627, June 1969.

16. —_ Wage, Hours, and Public Contracts Division, Fair Labor Standards Act of 1938, As Amended, Nov. 1966. 